\title{
Social Welfare Consequences of the Radius of Employment Decency
}

\author{
By Thomas Dickson Ndamsa*, Gladys Njang ${ }^{\dagger} \&$ Francis Menjo Baye
}

The private sector in Cameroon employs close to $90 \%$ of the labour force, and about $80 \%$ of those employed in this sector are in a situation of precarious employment. This paper investigated the private sector social welfare shares and impacts of employment decency among other regressed-income sources in Cameroon. Specifically, it (1) investigated the role of decent employment in shaping private sector inequality; (2) evaluated the share of decent employment in total social welfare of private sector households; and (3) examined the effect of growth in the mean value of decent employment on private sector social welfare. It employed the Cameroon Household Consumption Survey (CHCS III) conducted in 2007 by the Government's Institute of Statistics. Findings indicated that decent employments, human capital, and financial capital endowments have inequality-reducing effects. Our analysis further noted that good working conditions (decent employment), education and training facilities (human capital) as well as access to micro-credit (financial capital) accrue relatively more to the rich or privileged households than the poor or underprivileged households in the private sector. We found that a decision-maker who is absolutely equity seeking may lay more emphasis on micro-credit access, education and training programmes, and better working conditions, in that order, to obtain commendable social welfare outcomes. In addition, results indicated that if the decision-maker mediates 50:50 between efficiency and equity, then human capital endowments are ranked first followed by decent employment endowments in terms of social welfare enhancement. This order was maintained for more efficiency seeking policymakers. These findings indicated that policy measures focused on driving private sector working conditions, education and training facilities as well as improve micro-credit access should consider their relative disparities between the rich and the poor private sector households in order to better tap their inequality-reducing effects. (JEL D60, E24, D63)

Keywords: Decent Employment, Efficiency, Equity, Generalised Social Welfare Function and Private Sector.

\section{Introduction}

The past decade has witnessed a growing interest in the impact of development on poverty. This era is marked by burgeoning research interests and debates on the extent to which economic growth benefit the poor (Ravallion, 1998 and 2001, Ravallion and Datt 2000, 2002, Quah 2001, Ravallion and Chen 2003). One school

\footnotetext{
${ }^{*}$ Senior Lecturer, University of Bamenda, Cameroon.

${ }^{\dagger}$ Assistant Lecturer, University of Bamenda, Cameroon.

"Professor, University of Yaounde II, Cameroon.
} 
of the debate maintains that the potential benefits of economic growth to the poor are undermined or offset by the inadequate redistributive policies and by increases in inequality that accompany economic growth. Worthy of note, the UN (2015) posited that a continued lack of decent job opportunities will erode the potentials of the society to share in economic growth. This paper supports the UN (2015) by providing empirical evidence on the extent to which an increase in the situation of decent jobs can enhance social welfare in the private sector of employment. Another school argues that despite increased inequality in the liberal economic policies, open markets raise incomes of everyone in the society, including the poor, which proportionally reduce the incidence of poverty. However, we do not also have to forget that if open markets fail to consider people's social, economic and especially the fundamental employment rights of workers it may lead to deprivation. In effect, in the midst of globalization, the concern of policymakers should not be on which school is right or wrong, but rather on the ability to mediate between these prominent policy goals; income objectives (efficiency) and redistributive objectives (equity).

Poverty remains a major issue for developing countries, especially in SubSaharan Africa (SSA). For instance, Aoun (2004) intimated that poverty is an outsized and increasing problem in the world and he further underlined that most developing countries suffer from poverty. According to the World Bank (2000), SSA is one of the poorest regions in the world. The problem of widespread poverty in SSA is rooted in the economic downturn of the late 1980s. While jobs were at the core of economic policy even before the economic crisis, there was growing concern that many of the jobs being created were "vulnerable jobs", insecure in nature, marked by unstable pay and lack of representation. It is increasingly clear that employment is not always a guarantee to avoid poverty. A recent ILO (International Labour Organization) report estimates that roughly 500 million people (that is, $18 \%$ of the work force) in low income countries are 'working poor', living with an annual income below the poverty line (ILO 2007). Although these numbers have fallen, this decline has been driven essentially by development in China, South Asia, and middle-income countries. Despite the important gains during the second half of the 1990s, nearly 4 out of every 10 Cameroonians in 2001 were 'working poor', living with an annual income below the poverty line of FCFA 185,490 (F stands for franc and CFA for Communauté Financière d'Afrique ${ }^{1}$ ), roughly equivalent to US $\$ 1$ per person, per day, or FCFA 19,000 per month (Government of Cameroon, 2003). According to the Government of Cameroon (2007), the monetary poverty threshold in 2007 stood at 269,443 francs CFA per adult equivalent per year and the poverty situation between 2001 and 2007 remained almost the same; passing from $40 \%$ to 39.9\%. Between 2007 and 2014, poverty witnessed a slight decrease in headcount (by 2.4 points) but this reduction failed to meet the target of the current government's policy document (Growth and Employment Strategy Paper - GESP) to reduce poverty to 35\% in 2015.

\footnotetext{
${ }^{1}$ It is the currency used in Cameroon and in some central African countries.
} 
According to the World Follow-up Report of $2008^{2}$, halfway towards achieving the MDGs, the progress achieved in the world is not satisfactory, particularly in Africa. In Cameroon, poverty reduction is a burning concern of the government, worrisomely Cameroon did not meet the 2015 millennium target of reducing poverty by half; as monetary poverty incidence only reduced marginally between 2001 and 2014 (Government of Cameroon 2014). One attractive characteristic of income poverty in Cameroon is its sector disparity. According to the Government of Cameroon (2007), only $10.2 \%$ of public sector workers are working poor; living below a monthly income of about $22,454 \mathrm{CFA}^{3}$ francs compared to $44 \%$ in the private sector. More organised and off farm sectors appear to be routes out of poverty. This is because only $9.5 \%$ of workers in formal private employment are working poor compared to $46.8 \%$ in informal employment. Equally, $20.4 \%$ of those in nonfarm private sectors are working poor as opposed to $59 \%$ in farming activities.

The situation of income distribution in Cameroon depicts a widening gap between the poor and nonpoor, formal and informal workers as well as between workers employed in farm and nonfarm sectors. Formal private sector income inequality remained higher than informal sector inequality in 2007. Per capita income inequality among formal private sector households stood at $38.7 \%$ compared to $35.3 \%$ in the informal sector. The same scenario is observed for farm and nonfarm private employment sectors, where nonfarm sector inequality stood at $34.3 \%$ in 2007 as opposed to $30.4 \%$ in the farm sector (Government of Cameroon 2007). These observed disparities suggest the need to accompany or blend income growth policies with appropriate redistributive policies to ensure the fruits of growth benefit all sectors in the economy. This is also indication that not only GDP growth, but also other factors like income distribution patterns associated with socio-demographic factors should be considered to address welfare concerns of the poor and nonpoor. Such factors like decent employment, human capital, financial capital just to mention a few may help enhance total social welfare represented in terms of efficiency (household mean income) and equity (household income distribution). This way, this paper is conducted to address the measurement of social welfare received by private sector households on the basis of mean income and income distribution, using the generalised social welfare decomposition framework. The paper innovatively decomposes social welfare as a weighted sum of individual welfare of various regressed-income components or endowments.

Given that the growing concern of most development policymakers is to identify key variables-cum policies that can boost income growth and enhance equity, thus improving social welfare, the main research question here is: What are the social welfare impacts of decent employment and other regressed-income sources? Specifically, this paper attempts to provide answers to the following questions:

\footnotetext{
${ }^{2}$ World Development Indicators: Report on the progress of the achievement of the Millennium Development Goals by region.

${ }^{3}$ The annual poverty line was estimated at 269,443 CFA francs per adult equivalent per year (giving 22,454 CFA francs per adult equivalent per month).
} 
- How does decent employment shape private sector income inequality?

- What is the share of decent employment and other regressed-income components in total social welfare of private sector households?

- What are the impacts of an increase in the mean value of decent employment and other regressed-income components on total social welfare of private sector households?

The main objective of this paper is to evaluate the private sector social welfare impacts of employment decency and other regressed-income sources. The specific objectives are:

- To investigate the role of decent employment and other regressed-income components in shaping private sector inequality;

- To evaluate the share of decent employment and other regressed-income components in explaining total social welfare of private sector households;

- To examine the private sector social welfare impacts of an increase in the mean value of decent employment and other regressed-income components on;

- To provide targeted policy measures that tackle income growth and equity simultaneously.

These objectives may help inform policymakers better on regressed variablescum-policies which can impact both income inequality and poverty. Confirming this policy objective, Kakwani et al. (2006) asserts that a policy menu that targets both distributional concerns and poverty reduction worries could lead to the enhancement of both economic growth and equity.

The rest of the paper is organized as follows: Section II reviews the literature that has attempted to blend efficiency and equity in the analysis of social welfare; Section III presents the theoretical framework; Section IV develops the methodology of the study; Section V presents the findings; and Section VI hosts the concluding remarks and policy implications of the paper.

\section{Literature Review}

The concept of social welfare function, as intimated earlier, was first introduced by Bergson (1938). He considered the social welfare function as a real-valued function that ranks conceivable social states from lowest to highest. Samuelson (1949) in turn evaluated the various ways by which social welfare function can be used in welfare economics. Economic literature measures social welfare either cardinally in terms of monetary units (say CFA franc or Dollar) or ordinal in terms of Pareto efficiency. The ordinal approach is made up of the Lorenz Dominance and Generalised Lorenz Dominance approaches whereas the cardinal approach is the measurement of social welfare using the Sen social welfare function (Sen-SWF). The Sen-SWF takes as inputs any variable considered to affect economic welfare (for example life expectancy or per capita income) of 
the population (Sen 1970:33). In this perspective, credit access (Pitt and Khandker 2002, Khandker 2005) and employment/job quality (Andolfatto and Gomme 1998, ILO 2014, European Commission 2018) stand out as important inputs into the Sen-SWF. Cardinal measures, unlike ordinal measures, are not aggregated from individual utility functions.

The ordinal approaches hinge on Atkinson theorem (Atkinson 1970) which holds that the Lorenz Dominance is a necessary and sufficient condition to identify welfare superiority in the dominating distribution, for a policymaker who is income-seeking and inequality-averse. For this theorem, the mean of the dominating distribution should be the same or higher than that of the dominated distribution. In specific terms, social welfare is higher in distribution B than distribution $\mathrm{A}$ if the following conditions are verified: (i) the Lorenz Curve of distribution $\mathrm{B}$ dominates that of distribution $\mathrm{A}$; (ii) the distributions have the same mean income or the mean income in $\mathrm{B}$ is greater than that in $\mathrm{A}$; and (iii) the policymaker is income-seeking and inequality-averse (that is, SWF has positive first derivative and negative second derivative with respect to individual incomes).

Baluch and Razi (2007) as Mukhopadhaya (2003) has applied the ordinal approach in Pakistan and Singapore respectively. Baluch and Razi (2007) observed that while social welfare in the society increased over-time, their comparisons were ambiguous because Lorenz Curves were intersecting. In such situations, cardinal measures are more appropriate. Nonetheless, Mukhopadhaya (2003) suggested that in such a case it is possible to find out different concave utility functions that can rank two social situations differently.

Critics, championed by Shorrocks (1983), attacked on the premise that it permitted comparison only when distributions have the same mean and produced ambiguous results when Lorenz Curves intersect. In an attempt to resolve these insufficiencies of the Lorenz Dominance criterion, Shorrocks (1983) extended Atkinson's formulation by introducing the concept of Generalized Lorenz Dominance Approach. This approach was estimated by scaling the ordinary Lorenz curve up by the mean income. He indicated that even if ordinal Lorenz Curves of two distributions intersect, the condition of generalised Lorenz Dominance could still be satisfied by testing for higher order of dominance.

However, it was observed that Lorenz Dominance and generalised Lorenz Dominance criteria of welfare comparison provides only partial ordering of social welfare considering only the inequality aspect (Baluch and Razi 2007). Moreover, according to Baluch and Razi (2007), these criteria ignore the economic efficiency/ growth aspect of social welfare considerations. In addition, Mukhopadhaya (2001c) and Baye (2011) underscore that the generalised Lorenz Dominance has profound efficiency bias. After the demerits of the generalised Lorenz Dominance approach, the search is for an approach that will consider both equality and efficiency considerations of social welfare. Fortunately, the expectations of the literature found refuge in Sen (1974).

Sen (1974) in an attempt to address the insufficiencies of the Lorenz Dominance criteria introduced the Sen-SWF which judges trends in total welfare and trends in its components (equality and efficiency). The Sen-SWF, a cardinal SWF with complete ordering, can be employed to assign numerical values of 
all possible social situations in the income distribution space. Baluch and Razi (2007) have also applied the Sen-type SWF on data from Pakistan. They observed that an increase in mean income of $0.5 \%$ and income inequality of 0.16 resulted to a $16.1 \%$ increase in welfare of rural areas as opposed to urban areas where a lower growth rate of $1.1 \%$ and higher income inequality of 0.48 led to a fall in welfare by $5.1 \%$ between 2001 and 2002 .

However, some endeavours have questioned the sole reliability on the Pareto criterion of Sen-SWF. Mukhopadhaya (2001b) has questioned the philosophy of Paretian principle as a desirable property of the SWF. He further demonstrated that it is possible to generalise the widely used Sen-SWF, which can be non-Paretian under special circumstances and to allow mediation between efficiency and equity considerations. Mukhopadhaya (2001b) has applied the method (generalised SenSWF) using Australian data to decompose total welfare into different factor components of income (Earned Income, Unearned Income and Government Benefit). Baye (2011) has also employed it on Cameroon data to decompose trends in social welfare across regions (rural, semi-urban and urban).

Some literature has focused on investigating whether increases in global social welfare are accompanied by increases in global population size (Parfit 1984, Burns and Hart 2000 and Cockburn et al. 2014). The work of Cockburn et al. (2014) employed the critical-level generalized utilitarianism (CLGU) approach to investigate if global social welfare has improved in the last decades because of the substantial increase in global population. Their study underlined that global social welfare can be deemed to have increased between 1990 and 2005 if it is judged that lives with per capita yearly consumption of more than $\$ 1,248$ necessarily increase social welfare. They posited that the same conclusion can be made for Sub-Saharan Africa if and only if the same judgement can be made for lives with a level of per capita yearly consumption above $\$ 147$.

It is evident that most attempts in the literature limit analysis of social welfare on income/expenditure and completely ignore the determinants of income. This paper adopts a new analytical perspective that uses the information contained in income generating equations to account for total social welfare in a given population. The analytical perspective derived here has advantages of its own. Because it relies on a regression framework, it expresses the level of total social welfare as a function of the income determinants that are used in the regression of income.

\section{Theoretical Framework}

The concern of most development policymakers is to design policy intervenetions that can revamp growth (income growth) and reduce income inequality; this is tantamount to increasing efficiency and equity. Efficiency and equity, components of the SWF, can be tracked by a non-utilitarian form of the Bergson (1938)-Samuelson (1949) SWF as follows:

$W=W(Y, \theta)$ 
Where $\mathrm{W}$ is total social welfare, $\mathrm{Y}$ is total income representing efficiency and $\theta=\theta\left(x_{1}, x_{2}, x_{3}, \ldots ., x_{n}\right)$ stands for a measure representing inequality. For this SWF (equation 1), an increase in efficiency and inequality will increase and decrease social welfare (W), respectively. With a reading of this function, it is clear that many SWFs will verify the above conditions. In an attempt to render the welfare function in equation (1) more specific, Sen (1974 and 1979) using a nonutilitarian approach ${ }^{4}$ introduced axiomatically the following SWF:

$$
W=\mu(1-G)
$$

Where $\mu$ is the mean income of the population and $\mathrm{G}$ is the Gini inequality coefficient of the income distribution ${ }^{5}$. This function indicates that an increase in mean level of income will lead to a higher level of social welfare and an increase in income inequality will reduce social welfare. It can be shown that the Sen-SWF also obeys the Paretian principle. For the Sen-SWF, the rate of substitution between mean income (efficiency) and income inequality at a constant welfare level is written as follows:

$$
\frac{\partial G}{\partial \mu}=\frac{1-G}{\mu}
$$

From equations (2) and (3), the Sen-SWF is more sensitive to mean income than to inequality. Given that both $G$ and $u$ are determined by the income profile of the society and cannot be influenced by the policymaker or decision-maker at different levels of growth or income distribution, this SWF is not flexible. The marginal welfare change with respect to mean income, in this case, is $(1-G)$ which is a constant. In this perspective, for any inter-sector comparison, this SWF will always be biased in favour of more advanced economic sectors with higher per capita incomes and relatively low inequality. Equally, in the case of an international comparison, this SWF will always be unfair or biased in favour of developed countries with relatively high per capita incomes and relatively low inequality.

Conscious of these shortcomings of the Sen-SWF, Mukhopadhaya (2001a) proposed a general and flexible SWF for policy mediation by incorporating a trade-off parameter, $\beta$, between efficiency and equity. This way, we have:

$W=\mu^{\beta}(1-G) \quad \forall 0 \leq \beta \leq 1$

Equation (4) is non-Paretian if $\beta$ is less than 1 (since when $\beta=1$, the modified SWF becomes the Sen SWF, which is Paretian). With equation (6.4), social welfare will decrease if the benefits of a growth process only go to the

\footnotetext{
${ }^{4}$ Note that all utilitarian SWFs are Paretian.

${ }^{5}$ Sen (1976) shows that this index, calculated from the income distribution, 'is a sub-relation of social preference relation defined in the distribution of commodities'. Alternatively, Yitzhaki (1979, 1982) showed that this index could be based on relative deprivation. Sheshinski (1972) also derived this index from the Gini coefficient.
} 
richest person in the society (for $\beta<1$ ). When $\beta=0$, the SWF becomes a function of inequality $(\mathrm{G})$ regardless of the level of efficiency of the population (Mukhopadhaya 2001b).

With this modified SWF, the rate of substitution between inequality and efficiency at a constant welfare level is given by:

$$
\frac{\partial G}{\partial \mu}=\left(\frac{1-G}{\mu}\right) \beta
$$

With variable values of $\beta$ the decision-maker now has the choice of $\beta$ depending on whether she is more income-seeking than being inequality averse. Thus, the SWF is now flexible with respect to the trade-off between efficiency and equity. If the decision-maker considers efficiency to be more important than equality, she will choose a higher value of $\beta$ (close to one). In the contrary, if she is more inequality averse than income-seeking, she will go for a lower value of $\beta$ (close to zero).

This SWF may be criticized on the basis of its unfairness in favour of the poor in the population. For instance, if the income of the poorest person increases irrespective of the values of $\beta$ and $\mathrm{G}$, social welfare must increase. In this perspective, this SWF has some Rawlsian flavour; according to which an increase in the richest person's (sector's) income does not change social welfare. Fortunately enough, in our modified SWF, with $\beta<1$, an increase in the income of the richest person (or sector) causes social welfare to decrease. Thus, the class of SWF (with $\beta<1$ ) is non-Rawlsian and also non-Paretian.

Kaldor-Hicks efficiency criterion takes a rather deviated stands stressing on the compensation of losers. It supposes that a decision can be deemed to be more efficient if it produces a net gain to the society and enables any potential losers to be compensated from the net gain secured. Their position tailors somewhat with Pareto efficiency, where this compensation can occur through voluntary agreements between losers and those who gain. This theory is strongly criticised for blowing economic welfare/economic utility above other moral considerations.

\section{Methodology and Data used}

\section{Decomposition of Social Welfare (W) by Regressed-Income Components}

Our new analytical perspective to social welfare consists to use information contained in an income-generating equation to decompose social welfare. We propose in this paper to baptise this approach 'regression-base perspective to social welfare'. ${ }^{6}$ The regressed-income components or endowments retained here are decent employment, human capital, financial capital, and household demographics. These regressed-income components will be further discussed

\footnotetext{
${ }^{6}$ This approach to social welfare that springs from a regression analysis is first of its kind; it has seen light thanks to this paper. The appellation 'regression-based perspective to social welfare' is born in this paper.
} 
below. We hinge on the framework proposed in Mukhopadhaya (2001b) to implement this analytical perspective.

According to Rao (1967), the Gini coefficient $(G)$ of income inequality can be decomposed by components of income as follows:

$$
G=\sum_{m=1}^{M} S_{m} C_{m}
$$

Where:

$S_{m}=\frac{\mu_{m}}{\mu}$ stands for the factor share of the regressed-income component;

$C_{m}$ is the concentration coefficient of the regressed-income component $m$; and

$M$ is the total number of regressed-income components.

The concentration coefficient of the regressed-income component is calculated using the same formula as the Gini coefficient; the ranking will remain the same as in the case of the Gini coefficient ${ }^{7}$. The deviation of the Gini coefficient from the concentration coefficient, $C_{m}-G$, represents the direction of inequality augmenting or reducing effect of the regressed-income component $\mathrm{m}$. Essentially, if certain regressed-income components accrue relatively more to the poor households than the rich in the private sector (for example programmes like free education for all that favour the poor) the concentration coefficient will be negative. Conversely, if the regressed-income factor accrues more to the rich households (say investment income or loans) the concentration coefficient would be positive and will exceed the value of the Gini coefficient. This way, if the concentration coefficient of any regressed-income component is higher (lower) than the overall Gini, the component has an inequality augmenting (reducing) effect. Thus, an extra CFA franc directed to the component will increase (decrease) overall inequality.

According to Mukhopadhaya (2001b), total social welfare can be represented as a weighted sum of individual welfare of various regressed-income components as follows:

$W=\sum_{m=1}^{M} a_{m} W_{m}$

Where $W_{m}$ is the welfare of the $m^{\text {th }}$ regressed-income component and $a_{m}$ is the weight attached to the individual component's welfare.

The generalised SWF can be represented as the weighted sum of individual component's welfare following the steps below. From equations (6) and (7), total

\footnotetext{
${ }^{7}$ When a specific factor income is arranged in ascending order of total income and the proportion of factor incomes are plotted against the proportions of income units, we get the concentration curve. One minus twice the area of the concentration curve is the concentration index. Unlike Lorenz curve, the concentration curve may lie above the $45^{\circ}$ diagonal and in that case the concentration index will be negative. The value of the coefficient lies between $(-1,1)$ and, most importantly, it satisfies the Pigou-Dalton condition of transfer.
} 
social welfare, $\mathrm{W}$, is given by the sum of the product between the weights attached to the $M$ regressed-income components and the welfare of these components. Thus, we have:

$$
\begin{aligned}
W & =\mu^{\beta}(1-G) \\
& =\mu^{\beta}\left(1-\sum_{m=1}^{M} \frac{\mu_{m}}{\mu} C_{m}\right) \\
& =\mu^{\beta}-\sum_{m=1}^{M} \frac{\mu_{m}}{\mu^{1-\beta}} C_{m} \\
& =\sum_{m=1}^{M} \frac{\mu_{m}}{\mu} \mu^{\beta}-\sum_{m=1}^{M} \frac{\mu_{m}}{\mu^{1-\beta}} C_{m} \quad\left(\text { as } \sum_{m=1}^{M} \frac{\mu_{m}}{\mu}=1\right) \\
& =\sum_{m=1}^{M} \frac{\mu_{m}}{\mu^{1-\beta}}\left(1-C_{m}\right) \\
& =\sum_{m}\left[\left(\frac{\mu_{m}}{\mu}\right)^{1-\beta}\right]\left[\mu_{m}^{\beta}\left(1-C_{m}\right)\right] \\
& =\sum_{m} a_{m} W_{m} \quad(8)
\end{aligned}
$$

Where $a_{m}=\left(\frac{\mu_{m}}{\mu}\right)^{1-\beta}$ is the weight attached to the regressed-income component or endowment $m$ and $W_{m}=\mu_{m}^{\beta}\left(1-C_{m}\right)$ is the welfare that accrues to that regressed-income component.

Thus, the relative welfare due to this component is written as follows:

$\frac{a_{m} W_{m}}{W}=\frac{\left[\left(\frac{\mu_{m}}{\mu}\right)^{1-\beta}\right]\left[\mu_{m}^{\beta}\left(1-C_{m}\right)\right]}{\mu^{\beta}(1-G)}=\left(\frac{\mu_{m}}{\mu}\right)\left(\frac{1-C_{m}}{1-G}\right)$

When we are interested in measuring the relative contribution of a component to total social welfare (W), the question of trade-off between efficiency and equity does not arise; reason why $\beta$ does not appear in equation (9). In equation (9), the last term in parenthesis on the right hand side, $\frac{1-C_{m}}{1-G}$, has an attractive economic interpretation and can be called 'relative equity of component $m$ '. If the value of the relative equity of component $m$ is greater (less) than 1 (one), the component will have an inequality reducing (augmenting) effect. Worthy of note, the relative welfare share accruing to a regressed-income component depends on the relative mean income $\left(\frac{\mu_{m}}{\mu}\right)$ and the relative equity of the component (see equation 9).

The effect of growth (that is, growth in the mean value) in a component on the total social welfare of the population is an important policy question. It is answerable here by determining the elasticity of total social welfare with respect to a change in the mean amount or value of the component as in equation (10) below:

$$
\begin{aligned}
\epsilon_{m}^{W} & =\frac{\partial W / W}{\partial \mu_{m} / \mu_{m}}=\left(\frac{\partial W}{\partial \mu_{m}}\right)\left(\frac{\mu_{m}}{W}\right) \\
& =\left(\frac{\mu_{m}}{\mu}\right)\left(\frac{1-C_{m}}{1-G}\right)+\left(\frac{\mu_{m}}{\mu}\right)(\beta-1)
\end{aligned}
$$


Equation (10) is the elasticity of total social welfare, W, with respect to a change in the mean amount of component $m$. This elasticity attempts to paint a scenario where this change is distributed proportionately among all private sector individuals so that no change occurs in terms of inequality. Importantly, this elasticity equals the relative share of the component when $\beta=1$ (this is simply because the second term on the right hand side vanishes for $\beta=1$ ). When $\beta<1$, the elasticity is less than the relative share; since the second term on the right hand side becomes negative. If the factor share of the component is high, the second term of equation (10) will be large and will only reduce the elasticity more. Essentially, it is also true that if the factor share of the component is small the reducing effect will be small.

These elasticities have important policy guides; in comparing the elasticities of the different components, a policymaker or decision-maker may use her judgment for an equitable policy mix. With this procedure, we will be able to assess the effects of growth in decent employment (or the effects of an additional CFA franc directed to boost decent employment) on total social welfare. Equally, we will provide the decision-maker with sound knowledge on the effects of growth in human capital endowment, improvement in credit access, as well as better family planning schemes on total social welfare of private sector households in Cameroon. In this context, policy targeting to improve social welfare may prioritise components for which both the relative share of welfare and the elasticity with respect to the mean amount are high.

\section{Combining Income Components}

Given the following linear regression, with no constant $^{8}$ (as per Control Function Regression ${ }^{9}$ in appendix - Table A4):

$$
\begin{aligned}
& y_{i}=\beta_{1} x_{i, 1}+\beta_{2} x_{i, 2}+---+\beta_{m} x_{i, m}+\varepsilon_{i} \\
& m=1,2, \ldots \ldots, M \text { and } i=1,2, \ldots \ldots, n
\end{aligned}
$$

Where, $\mathrm{Y}_{\mathrm{i}}$ is per capita monthly income of household $i ; \beta_{0}, \beta_{1}, \ldots, \beta_{m}$ are parameters to be estimated; $x_{i}(i=1,2, \ldots, n)$ the set of independent variables; and $\varepsilon$ is the error term.

It is possible from the regression results to generate the estimated income flows attributable to the various explanatory variables. These estimated income flows are obtained from $\hat{y}^{m}=X \hat{\beta}_{m}$. It then follows that total income is the sum of these income flows plus the residual:

\footnotetext{
${ }^{8}$ Given that the constant is not an income source per se, this regression was done without the constant term.

${ }^{9}$ The results internalize for potential endogeneity of employment decency and unobserved heterogeneity bias which standard Ordinary Least Squares may suffer from.
} 


$$
y_{i}=\sum_{m=1}^{M+1} \hat{y}_{i}^{m} \quad \text { where } \hat{y}_{i}^{m}= \begin{cases}\hat{\beta}_{m} x_{i}^{m} & \text { for } \mathrm{m}=1 \ldots \ldots . \mathrm{M} \\ \hat{\varepsilon}_{i} & \text { for } \mathrm{m}=\mathrm{M}+1\end{cases}
$$

The regressed-income source ${ }^{10}$ ' 1 ', $C_{1}$, is obtained as follows:

$$
C_{1}=y_{i}-\sum_{m \neq 1}^{M} \hat{y}_{i}^{m}
$$

Which can also be written:

$$
C_{1}=y_{i}-\left[\sum_{m \neq 1}^{M-1} \hat{y}_{i}^{m}-\hat{\varepsilon}_{i}\right]
$$

The other regressed-income sources $\left(C_{2}, C_{3}, \ldots \ldots, C_{M}, C_{M+1}\right)$ are obtainable in the same manner. Thus we have:

$$
\begin{gathered}
y=\hat{y}+\varepsilon \\
\text { Where } \hat{y}=C_{1}+C_{2}+C_{3}+\ldots \ldots+C_{M} \text { and } \varepsilon=C_{M+1}
\end{gathered}
$$

These regressed-income sources can now be combined in groups of regressedincome components according to the needs of the study. For instance, $C_{1}+C_{2}$ could form a component, $C_{3}+C_{4}$ another component and so on. The regressedincome components or endowments retained in our study are decent employment, human capital, financial capital, household demographics as per Table 1 below.

\section{Data Used}

The main data used here is the Cameroon household consumption survey (CHCS III) conducted in 2007 by the Government's Institute of Statistics. The variables used in this paper are solely inspired from the control function regression analysis placed at the appendix. However, in the analysis of social welfare here, we considered a decent employment indicator; whose primary variables/categories and its construction are displayed in the appendix as well. After combination of income sources, we obtained the following components:

\footnotetext{
${ }^{10}$ The use of the term 'regressed-income source/component' is inspired from the works of Wan (2002) and Morduch and Sicular (2002), but this appellation is unique in this paper; it refers to income sources/components generated from a regression model.
} 
Table 1. Combined Income Components

\begin{tabular}{|l|l|}
\hline Combined Income Components & Income Sources \\
\hline Decent employment endowment & Decent employment indicator \\
\hline Human capital endowment & $\begin{array}{l}\text { Experience, experience square; years of schooling; } \\
\text { and head of enterprise. }\end{array}$ \\
\hline Financial capital endowment & Access to micro-credit \\
\hline Household demographics & $\begin{array}{l}\text { Children below five years old; currently married; } \\
\text { male gender type; and urban residency }\end{array}$ \\
\hline Indirect decent employment endowments & $\begin{array}{l}\text { Predicted residual of decency and the interaction } \\
\text { term (interaction between predicted residual of } \\
\text { decency and decency indicator) }\end{array}$ \\
\hline Other income sources & $\begin{array}{l}\text { Residual term (sources not captured in the } \\
\text { structural equation) }\end{array}$ \\
\hline
\end{tabular}

Source: Authors.

\section{Empirical Results}

\section{Descriptive Statistics}

The descriptive statistics of the combined income components or endowments of the dependent variable (per capita household monthly income) are submitted in Table 2.

From Table 2, it is evident that in the private sector, human capital endowments have the highest share of the dependent variable, followed by decent employment endowments and household demographics, in the light of their means. However, financial capital endowments and other income endowments, not captured in our regression, are also potent when it comes to private sector household income. The indirect decent employment endowments have a lessening effect on the dependent variable.

Table 2. Descriptive Statistics of Combined Income Components

\begin{tabular}{|l|c|c|c|}
\hline Variables & Number of Observations & Mean & Standard Deviation \\
\hline \multicolumn{4}{|c|}{ Combined Income Components } \\
\hline $\begin{array}{l}\text { Decent employment } \\
\text { endowments }\end{array}$ & 9219 & 8368.495 & 11945.15 \\
\hline $\begin{array}{l}\text { Human capital } \\
\text { endowments }\end{array}$ & 9219 & 10719.13 & 4493.137 \\
\hline $\begin{array}{l}\text { Financial capital } \\
\text { endowments }\end{array}$ & 9219 & 414.958 & 641.0229 \\
\hline Household demographics & 9219 & 2176.465 & 4785.521 \\
\hline $\begin{array}{l}\text { Indirect decent } \\
\text { employment endowments }\end{array}$ & 9219 & -596.530 & 8185.521 \\
\hline Other income sources & 9219 & 427.312 & 17452.79 \\
\hline Total income & 9219 & 21509.83 & 20357.37 \\
\hline
\end{tabular}

Source: Computed by author from CHCS III Survey Data. 
Regression-based Analytical Perspective of the Generalised Class of Sen-SWF

Decomposition of the Generalised Class of Sen-SWF by Regressed-Income Components

Table 3 submits the necessary statistics to serve in the decomposition of total private sector welfare by regressed-income components or endowments. The first and second columns present the mean of each regressed-income component and its share in private sector total mean income and the last column hosts their concentration coefficients. The share of human capital endowments in total mean income is highest at about $49.8 \%$, followed by that decent employment endowment $(38.9 \%)$ and household demographics $(10.1 \%)$. The shares of the other endowments in total mean income are marginal and can come in the following order: other income sources (2.0\%); financial capital endowment $(1.9 \%)$; and indirect decent employment endowment (-2.7\%).

The Gini coefficient of total private sector household per capita income is estimated at 0.38 (Table 3 ). The values of the concentration coefficients of decent employment, human capital, and financial capital endowments are less than the overall Gini coefficient, illustrating their inequality-reducing effects. However, it should be noted that good working conditions (decent employment), higher education and training facilities (human capital) as well as access to micro-credit (financial capital) accrue relative more to the rich or privileged households than the poor or underprivileged in the private sector; reason why the values of their concentration coefficients though less than the Gini are positive. This is indication that though they have inequality-reducing effects, policy measures driven in their directions should consider their relative disparities between the rich and the poor private sector households in order to better tap these effects (inequality-reducing effects). These policy measures should ensure a level playing ground with equal opportunities.

In a nutshell, the values of the concentration coefficients of household demographics and indirect decent employment are in excess of the Gini coefficient, indicating their inequality-augmenting effects. Concerning household demographics, this is implication that family planning measures (like birth control to target the number of young children in households) and geographic considerations (zone of residence) be made part and parcel of policy arrangements interested to affect inequality. For indirect decent employment, the very high value of its concentration coefficient indicates that the power to bargain better or good working conditions and the ability to manage household shocks (like unemployment and birth) accrue overwhelmingly to the rich households in the private sector. 
Table 3. Factor Shares of Income Components and Concentration Coefficients

\begin{tabular}{|l|c|c|c|}
\hline Components & $\begin{array}{c}\text { Mean Value } \\
\boldsymbol{\mu}_{\boldsymbol{m}}\end{array}$ & $\begin{array}{c}\text { Factor Shares } \\
\boldsymbol{\mu}_{\boldsymbol{m}}\end{array}$ & $\begin{array}{c}\text { Concentration } \\
\text { Coefficients } \\
\boldsymbol{\boldsymbol { m }}_{\boldsymbol{m}}\end{array}$ \\
\hline Decent employment endowment & 8368.50 & 0.389 & 0.250 \\
\hline Human capital endowment & 10719.13 & 0.498 & $(0.012)$ \\
\hline & & $(0.009)$ & 0.091 \\
\hline Financial capital endowment & 414.96 & 0.019 & $0.006)$ \\
\hline & & $(0.001)$ & $(0.034)$ \\
\hline Household demographics & 2176.47 & 0.101 & 0.567 \\
\hline & & $(0.007)$ & $(0.069)$ \\
\hline $\begin{array}{l}\text { Indirect Decent employment } \\
\text { endowment }\end{array}$ & -596.53 & -0.027 & 0.933 \\
\hline & & $(0.009)$ & $(0.244)$ \\
\hline Other income sources & 427.31 & 0.020 & 0.324 \\
\hline & & $(0.014)$ & $(7.087)$ \\
\hline Overall private sector & 21509.83 & 1.000 & $0.380 *$ \\
\hline & & $(0.000)$ & $(0.006)$ \\
\hline
\end{tabular}

Source: Calculated by author from CHCS III Survey Data using DASP 2.1 (DASP: Distributive Analysis STATA Package).

Note: *this is the Gini coefficient and standard errors are in parentheses.

Table 4 presents social welfare generated by regressed-income components, that is, social welfare attributable to each regressed-income endowment across the parameter $\beta \in[0,1]$. An equity seeking decision-maker will prefer $\beta=0$ which side-lines the effects of mean incomes on social welfare and only focuses on equity. In this perspective, financial capital endowment is classified first followed closely by human capital and decent employment endowments in terms of social welfare. Thus, this decision-maker who is absolutely equity seeking may lay more emphasis on micro-credit access, education and training programmes, and better working conditions to obtain commendable social welfare outcomes. However, in a situation of limited resources, we may advise an absolute equity seeking decision-maker to give priority to financial capital, human capital and decent employment endowments in that order.

In a nutshell, the values of the concentration coefficients of household demographics and indirect decent employment are in excess of the Gini coefficient, indicating their inequality-augmenting effects. Concerning household demographics, this is implication that family planning measures (like birth control to target the number of young children in households) and geographic considerations (zone of residence) be made part and parcel of policy arrangements interested to affect inequality. For indirect decent employment, the very high value of its concentration coefficient indicates that the power to bargain better or good working conditions and the ability to manage household shocks (like unemployment and birth) accrue overwhelmingly to the rich households in the private sector. 
If the decision-maker mediates 50:50 between efficiency and equity ( $\beta=0.5$ ), then human capital endowments are ranked first in terms of social welfare, with a numerical value in excess of total social welfare and it is followed by decent employment endowments. In this case, financial capital endowments rank fourth after household demographics in the third position. Thus, a decision-maker who gives the same degree of importance to efficiency and equity considerations in the quest to improve social welfare may be encouraged to prioritise policy measures that boost human capital and improve working conditions of household heads. This observation also holds for values of the parameter $\beta>0.5(\beta=0.75$ and 1$)$. Thus, an efficiency seeking policymaker may choose interventions to improve human capital and working conditions.

Table 4. Decomposition of the Generalized Social Welfare Function by Regressed Income Components

\begin{tabular}{|l|c|c|c|c|}
\hline & $\boldsymbol{W}_{m}(\boldsymbol{\beta}=0)$ & $\boldsymbol{W}_{m}(\boldsymbol{\beta}=0.5)$ & $\boldsymbol{W}_{m}(\boldsymbol{\beta}=0.75)$ & $\boldsymbol{W}_{m}(\boldsymbol{\beta}=1)$ \\
\hline $\begin{array}{l}\text { Decent } \\
\text { employment } \\
\text { endowment }\end{array}$ & 0.75 & 68.61 & 656.22 & 6276.38 \\
\hline $\begin{array}{l}\text { Human capital } \\
\text { endowment }\end{array}$ & 0.909 & 94.11 & 957.60 & 9743.69 \\
\hline $\begin{array}{l}\text { Financial capital } \\
\text { endowment }\end{array}$ & 0.965 & 19.66 & 88.72 & 400.44 \\
\hline $\begin{array}{l}\text { Household } \\
\text { demographics }\end{array}$ & 0.433 & 20.20 & 137.98 & 942.41 \\
\hline $\begin{array}{l}\text { Indirect decent } \\
\text { employment } \\
\text { endowment }\end{array}$ & 0.067 & - & -39.97 & 288.86 \\
\hline $\begin{array}{l}\text { Other income } \\
\text { sources }\end{array}$ & 0.62 & 90.93 & 1101.21 & 13336.09 \\
\hline Total social welfare & 0.676 & 13.97 & 63.53 & -39.97 \\
\hline
\end{tabular}

Source: Calculated from CHCS III Survey Data using DASP 2.1 Software for Distributive Analysis. $W_{m}$ is the welfare share of endowment $m$.

Importantly, when $\beta=1$, we have the Sen SWF, which blows the efficiency consideration over the equity consideration. With these findings, we can observe that changes in $\beta>0$ are not sensitive to the ranking of regressed incomecomponents (Table 4). This observation is indicative of the trading of equity for efficiency as the parameter, $\beta$, is brought in. This way, efficiency considerations are more vital than equity considerations in determining social welfare. Nonetheless, other income sources, not captured in our regression, are also potent in generating social welfare and indirect decent employment endowments have diluting effects on private sector social welfare when $\beta=1$. 
Table 5. Contributions of Regressed-Income Endowments to Social Welfare and its Components

\begin{tabular}{|l|c|c|c|}
\hline & $\begin{array}{c}\text { Factor } \\
\text { share } \\
\left(\frac{\boldsymbol{\mu}_{m}}{\boldsymbol{\mu}}\right)\end{array}$ & $\begin{array}{c}\text { Relative equity } \\
\left(\frac{\mathbf{1}-\boldsymbol{C}_{m}}{\mathbf{1}-\boldsymbol{G}}\right)\end{array}$ & $\begin{array}{c}\text { Relative share of social } \\
\text { welfare }\left(\frac{\boldsymbol{a}_{m} \boldsymbol{W}_{m}}{\boldsymbol{W}}\right)\end{array}$ \\
\hline Decent employment endowment & 0.389 & 1.210 & 0.470 \\
\hline Human capital endowment & 0.498 & 1.466 & 0.730 \\
\hline Financial capital endowment & 0.019 & 1.556 & 0.029 \\
\hline Household demographics & 0.101 & 0.698 & 0.070 \\
\hline $\begin{array}{l}\text { Indirect decent employment } \\
\text { endowment }\end{array}$ & -0.027 & 0.108 & -0.003 \\
\hline Other income endowments & 0.019 & 1.090 & 0.021 \\
\hline
\end{tabular}

Source: Calculated from Table 3 using Microsoft Excel.

\section{$\underline{\text { Relative Contributions of Regressed-Income Components to Social Welfare }}$}

Table 5 hosts the relative share of income, the relative equity, and the relative share of social welfare for each regressed-income component. The values of the relative equity of decent employment, human capital, financial capital endowments, and other income sources are greater than one, further indicating that these components or endowments have inequality-reducing effects. This implies that if an extra CFA franc goes to boost decent employment, and if proportionately distributed, inequality will reduce. Worthy to note is also the observation that household demographics and indirect decent employment endowments are inequality-augmenting; since the values of their relative equities fall below unity. These observations further confirm the analysis done so far.

In Table 5, the relative share of human capital endowments to overall private sector social welfare is outstanding, followed by that of decent employment and household demographics. Human capital alone accounts for about $73.0 \%$ and decent employment about 47\%. Household demographics make about $7.0 \%$, financial capital about $2.9 \%$, other income sources about $2.1 \%$ while indirect decent employment dilutes overall social welfare by about $0.3 \%$. These relative welfare shares are also interpreted as the elasticities of social welfare with respect to equity $\left(1-C_{m}\right)$, maintaining the mean value of the component unchanged (Mukhopadhaya 2001a). Thus, policy efforts that focus on the twin goal of improving equality and boosting overall welfare among private sector household heads or workers are advised to prioritise human capital and decent employment endowments in their policy menu.

Elasticities of Social Welfare with respect to Growth in Regressed-Income $\underline{\text { Components }}$

Table 6 addresses the elasticity of social welfare with respect to a change in the mean value of each income component for different values of $\beta$. These elasticities identify quantitatively the expected change in total welfare for a $1 \%$ 
increase in the mean amount of a given regressed-income endowment (apportioned proportionately among all private sector individuals so that no change occurs in terms of inequality). In Table 6, this elasticity is highest with human capital endowment across the different values of the parameter, $\beta$. The elasticity of welfare with respect to decent employment endowment ranked second after human capital for an equity and efficiency $(\beta=0.75)$ seeking policymaker. This means that if an extra CFA franc goes to boost working conditions and is distributed proportionately to all private sector workers or household heads, social welfare will increase considerably.

Table 6. Elasticity of Social Welfare with respect to a Change in the Mean Value of each Regressed-Income Endowment

\begin{tabular}{|l|c|c|c|}
\hline & $\boldsymbol{\epsilon}_{\boldsymbol{\mu}_{m}}^{\boldsymbol{W}}(\boldsymbol{\beta}=\mathbf{0 . 5})$ & $\boldsymbol{\epsilon}_{\boldsymbol{\mu}_{m}}^{\boldsymbol{W}}(\boldsymbol{\beta}=\mathbf{0 . 7 5})$ & $\boldsymbol{\epsilon}_{\boldsymbol{\mu}_{m}}^{\boldsymbol{W}}(\boldsymbol{\beta}=\mathbf{0 . 9})$ \\
\hline Decent employment endowment & 0.276 & 0.373 & 0.432 \\
\hline Human capital endowments & 0.481 & 0.606 & 0.680 \\
\hline Financial capital endowment & 0.020 & 0.025 & 0.028 \\
\hline Household demographics & 0.020 & 0.045 & 0.060 \\
\hline $\begin{array}{l}\text { Indirect decent employment } \\
\text { endowments }\end{array}$ & 0.011 & 0.004 & 0.000 \\
\hline Other income endowments & 0.011 & 0.016 & 0.019 \\
\hline
\end{tabular}

Source: Calculated from Tables 3 and 5 using Microsoft Excel. $\epsilon_{\mu_{m}}^{W}$ is the elasticity of social welfare $(W)$ with respect to a change in the mean value of an endowment or a component $\left(\mu_{m}\right)$.

The numerical values of these elasticities are non-negligible for financial capital endowments and household demographics, but very low with indirect decent employment endowment for all values of $\beta$. Thus, a decision-maker who is either midway between efficiency and equity $(\beta=0.5)$ or more efficiency seeking than inequality averse $(\beta=0.75$ and 0.9$)$ in the quest to improve social welfare, may be advised to prioritise human capital and direct decent employment endowments in a situation of tight budgetary resources. The prominent elasticities of welfare registered with human capital and direct decent employment endowments are attributable more to total income share than to relative equity. This is because their rankings in terms of elasticity mimic that in terms of income share and not relative equity. This finding further substantiates our first hypothesis of study. In terms of income share, human capital ranks first and direct decent employment comes second; obeying their elasticity rankings, whereas in terms of relative equity, they come in the second (human capital) and third (direct decent employment) positions after financial capital endowment (Table 6). Thus, if target endowments or components were needed for policy purpose, they will be human capital and direct decent employment. 


\section{Concluding Remarks and Policy Implications}

The paper conducted the analysis of social welfare received by private sector households on the basis of mean income and income distribution. The paper proposed a new analytical perspective of social welfare that decomposed it as a weighted sum of individual welfare of various regressed-income components or endowments. This way, the paper employed the information contained in an income generating equation to account for total social welfare in the private sector in Cameroon. For this purpose, it combined the regressed-income sources into the following endowments or components: decent employment, human capital, financial capital, household demographics, and indirect decent employment endowments. This paper attempted to evaluate the share of each regressed-income component in social welfare and tease-out the effect of growth in each regressedincome component on total social welfare of private sector households.

The share of human capital endowments in total mean income was highest, followed by that of decent employment endowment and household demographics. Decent employments, human capital, and financial capital endowments were found to have inequality-reducing effects, as their concentration coefficients fell well below the overall Gini coefficient. Our analysis further noted that good working conditions (decent employment), education and training facilities (human capital) as well as access to micro-credit (financial capital) accrue relatively more to the rich or privileged households than the poor or underprivileged households in the private sector ${ }^{11}$; reason why the values of their concentration coefficients though less than the Gini were positive. This finding indicated that policy measures focused on driving private sector working conditions, education and training facilities as well as improve micro-credit access should consider their relative disparities between the rich and the poor private sector households in order to better tap their inequality-reducing effects. On the contrary, the values of the concentration coefficients of household demographics and indirect decent employment were in excess of the Gini coefficient, indicating their inequalityaugmenting effects. This result implied that family planning measures (like birth control to target the number of young children in households) and geographical considerations (zone of residence) are made an essential part of policy arrangements geared at addressing inequality. This finding underlined also that institutions (ministerial delegations of labour, trade unions, international labour organisation just to mention a few) should mobilise more efforts to ensure workers are protected and working conditions are made better.

We found that for an equity seeking decision-maker who prefers $\beta=0$, financial capital endowment was classified first followed closely by human capital and decent employment endowments in terms of welfare. This result implied that a decision-maker who is absolutely equity seeking may be encouraged to lay more emphasis on micro-credit access, education and training programmes as well as

\footnotetext{
${ }^{11}$ According to the Government of Cameroon (2007), out of the total number who obtained credit in $2007,84.4 \%$ were from rich households and $15.6 \%$ from poor households. It also underlined that better working conditions (stable remuneration, contract employment etc.) are more widespread among the rich than the poor households.
} 
better working conditions to obtain commendable welfare outcomes. For a decision-maker who is midway between efficiency and equity $(\beta=0.5)$, human capital endowments was ranked first in terms of social welfare, with a numerical value in excess of total welfare, and was followed by decent employment endowments. This finding implied that a decision-maker who gives the same degree of importance to efficiency and equity considerations in the quest to improve social welfare should be encouraged to prioritise policy measures that boost human capital and improve working conditions of private sector household. This observation and policy implication hold for decision-makers who are more efficiency seeking than equity $(\beta=0.75$ and 1$)$.

In terms of relative social welfare share, human capital endowments registered the highest share to overall private sector social welfare, followed by that of decent employment and household demographics. The elasticity of welfare with respect to human capital was highest across the different values of the parameter, $\beta$. That of welfare with respect to decent employment ranked second after human capital. This finding indicated that if an extra CFA franc goes to boost working conditions and is distributed proportionately to all private sector workers, social welfare would increase considerably. The numerical values of these elasticities were also considerable with household demographics, but lower with financial capital endowments for all values of $\beta$. This result further implied the importance of human capital and good working conditions in determining social welfare. The prominent elasticities of social welfare registered with human capital and decent employment were found to be attributable more to total income share than to relative equity.

\section{References}

Andolfatto D, Gomme P (1998) Unemployment and Economic Welfare. Economic Review 1998: Q3. Available at: http://clevelandfed.org/research/review/.

Aoun A (2004) Poverty Alleviation in the Developing Economies: the Leading Issues. NEW MEDII N 1: 2004

Asselin L M (2002) Composite Indicator of Multidimensional Poverty. CECI: June 2002.

Atkinson AB (1970) On the Measurement of Inequality. Journal of Economic Theory 2(3): 244-263.

Baluch MUH, Razi S (2007) Social Welfare Measure in Pakistan an Ordinal and Cardinal Approach. Pakistan Economic and Social Review 45(1): 55-88.

Baye MF (2011) A Gini-Based generalised Decomposition Analysis of Social Welfare Trends in Cameroon. African Journal of Economic Policy 18(1): 1-32.

Benzécri JP (1979) Sur le Calcul des Taux d'Inertie dans l'Analyse d'un Questionnaire. Les Cahiers de l'Analyse des Données 4: 377-378.

Bergson A (1938) A Reformulation of certain aspects of Welfare Economics, Quarterly Journal of Economics 52(2): 310-34.

Burns J, Hart (2000) Bentham, Jeremy. A Comment on the Commentaries and a Fragment on Government. In J Burns (ed) The Works of Jeremy Bentham. USA: Charlottesville, Virginia. 
Cockburn J, Duclos J and Zabsonré A (2014) Is Global Social Welfare Increasing? A Critical-Level Enquiry, Centre de recherche sur les risques les enjeux économiques et les politiques publiques, www.crrep.ca.

European Commission (2018) Employment and Social Developments in Europe. Directorate- General for Employment Social Affairs and Inclusion. Annual Review 2018.

Government of Cameroon (2003) Poverty Reduction Strategy Paper, August 2003, Republic of Cameroon, Yaoundé.

Government of Cameroon (2007) Enquête Camerounaise Auprès des Ménages, ECAMIII, National Institute of Statistics 2007, Yaoundé.

Government of Cameroon (2014) Enquête Camerounaise Auprès des Ménages, ECAMIV, National Institute of Statistics 2014, Yaoundé.

ILO (2014) Developing with Jobs. World of Work Report 2014. Revised Edition.

ILO (2007) ILO Report on Key indicators of the Labour Market. 5th Edition, International Labour Office, Geneva 2008.

Kakwani N M, Neri and Son H H (2006) Linkages between Growth, Poverty and the Labour Market, paper presented in a keynote address at the 5th General Meeting of the PEP Research Network, June 18-22, 2006, Addis Ababa, Ethiopia.

Kamgnia, Dia B, Wangun SL, Tatsinkou C, Afor J (2008) Benefices acquis et ciblage des pauvres dans les Depenses Publiques de sante et d'éducation au Cameroun. PEP research network, PMMA Working Paper 2008-08.

Khandker SR (2005) Microfinance and Poverty: Evidence Using Panel Data from Bangladesh. World Bank Economic Review 19(2): 263-286.

Ki J B, Faye S, and Faye B (2005) Multidimensional Poverty in Senegal: A NonMonetary Basic Needs Approach. Final Report, PMMA Working Paper-PEP.

Morduch J, Sicular T (2002) Rethinking inequality decomposition with evidence from rural China. Economic Journal 112: 93-106.

Mukhopadhaya P (2001a) A Generalized Social Welfare Function, Its Decomposition and Application, Department of Economics, National University of Singapore, Working Paper 0119. DOI= http://www.fas.nus.edu.sg/ecs/pub/wp/wp0119.pdf.

Mukhopadhaya P (2001b) A Generalised Social Welfare Function and its Disaggregation by Components of Income: The Method and Application, Department of Economics, National University of Singapore, Working Paper 0121. DOI = http://www.fas.nus. edu.sg/ecs/pub/wp/wp0121.pdf.

Mukhopadhaya P (2001c) Efficiency Criteria and the Sen-type Social Welfare Function", Department of Economics, National University of Singapore, Working Paper 0114. DOI= http://www.fas.nus.edu.sg/ecs/pub/wp/wp0114.pdf.

Mukhapadhaya P (2003) The ordinal and cardinal judgment of social welfare change in Singapore, 1982-99. The Developing Economies 61(1): 65-87.

Nenadic O, Greenacre M (2007) Computation of Multiple Correspondence Analysis. With code in R, BBVA Foundation, Madrid.

North D (1990) Institutions, Institutional Change and Economic Performance. Cambridge: University Press.

Pagès N (2003) Hétérogénéité des systèmes d'emploi urbain et vulnérabilité au travail: application aux entreprises et aux petites unités productives en Côte d'Ivoire. 3rd Conference sur l'approche des capacités: d'un développement viable à une liberté durable. Italy: University of Pavia, September 8-10.

Parfit D (1984) Reasons and Persons. Oxford: Oxford University Press. 
Pitt MM, Khandke SR (2002) The Impact of Group-Based Credit Programs on Poor Households in Bangladesh: Does the Gender of Participants Matter? Journal of Political Economy 106(5): 958-996.

Quah D (2001) Some simple arithmetic on how income inequality and economic growth matter", Paper presented at WIDER conference on Growth and Poverty, 25- 26 May 2001, Helsinki.

Rao VM (1967) Two decomposition of concentration ratio. Journal of Royal Statistical Society Series A(132): 428-435.

Ravallion M (1998) Does aggregation hide the harmful effects of inequality on growth? Economics Letters 61: 73-77.

Ravallion M (2001) Growth, Inequality and Poverty: Looking beyond Averages. World Development 29(11): 1803-15.

Ravallion M, Datt G (2000) When growth is pro-poor? Evidence from the diverse experience of Indian states, World Bank Policy Research, Working Paper 2263.

Ravallion M, Datt G (2002) Why Has Economic Growth Been More Pro-Poor in Some States of India than Others? Journal of Development Economics 68(2): 381-400.

Ravallion M and Chen S (2003) Measuring Pro-poor Growth. Economic Letters 78(1): $93-$ 99.

Samuelson PA (1949) Foundation of Economic Analysis. Cambridge: Harvard University Press.

Sen AK (1970) Collective Choice and Social Welfare (description), Chapter 3, "Collective Rationality". New York: Oxford University Press.

Sen AK (1974) Informational bases of alternative welfare approaches: aggregation of income distribution. Journal of Public Economics 3(4): 387-403.

Sen AK (1976) Liberty, Unanimity and Rights. Economica 43(171): 217-245.

Sen AK (1979) The welfare basis of real income comparisons: A survey. Journal of Economic Literature 17(1): 1-45.

Sheshinski E (1972) Relation between a social welfare function and the Gini Index of income inequality. Journal of Economic Theory 4(1): 98-100.

Shorrocks AF (1983) Rethinking Income Distributions. Economica 50: 3-17

United Nations (2015) United Nations Sustainable Development Goals, Goals adopted by the United Nations Member States. New York: United Nations.

Wan GH (2002) Regression-Based inequality decomposition: pitfalls and a solution procedure. Helsinki-Finland: UNU-WIDER Discussion paper 2002/101.

World Bank (2000) World Development Report 2000/01: Attacking Poverty. Washington DC.

World Follow-up Report (2008) World Development Indicators: Report on the progress of the achievement of the Millennium Development Goals by region. Washington DC.

Yitzhaki S (1979) Relative deprivation and the Gini coefficient. Quarterly Journal of Economics 93(2): 321-324.

Yitzhaki S (1982) Relative deprivation and the economic welfare. European Economic Review 17(1): 99-113. 


\section{Appendices}

Appendix 1: Multiple Correspondence Analysis (MCA) of Employment Decency

To construct the employment decency indicator, we employ the MCA as developed by Asselin (2002) and used by Ki et al. (2005) and Kamgnia Dia et al. (2008).

Table A1 presents the explained inertia by the factor axes. From Table A1, it follows that the first factor axis that represents almost $29 \%$ of total inertia (quantity of information) ${ }^{12}$ is the one that describes better employment quality of workers.

Table A1. Explained Inertia by the Factor Axis

\begin{tabular}{|l|c|c|c|}
\hline & Principal Inertia & Percentage & Cumulated percentage \\
\hline Factorial axis 1 & 0.57 & 28.5 & 28.5 \\
\hline Factorial axis 2 & 0.23 & 11.3 & 39.8 \\
\hline Total inertia & 2.00 & & \\
\hline
\end{tabular}

Source: Author.

Table A2 hosts the initial indicator variables/categories used for the construction of employment decency (column 1). The scores of the initial indicators coded in 0/1 obtained with the MCA and the contributions of the various categories are presented in Table A2. This table hosts the initial scores on the first axis as well as the squared correlations or squared cosines which represent the quality of representation of each initial indicator.

Table A2. Scores, Contributions and Squared Cosines of MCA on the Initial Indicators of Employment Quality

\begin{tabular}{|l|c|c|c|c|c|}
\hline $\begin{array}{l}\text { Variables/ } \\
\text { categories }\end{array}$ & $\begin{array}{c}\text { Initial } \\
\text { scores on } \\
\text { the First } \\
\text { axis }\end{array}$ & $\begin{array}{c}\text { Squared } \\
\text { correlations }\end{array}$ & Contributions & $\begin{array}{c}\text { Numbers } \\
\text { of } \\
\text { observations }\end{array}$ & Percentage \\
\hline $\begin{array}{l}\text { Employment } \\
\text { contract }\end{array}$ & 2.147 & 0.292 & 4.59 & 1,302 & 11.43 \\
\hline $\begin{array}{l}\text { Open-ended } \\
\text { (written) }\end{array}$ & 1.223 & 0.047 & 0.79 & 749 & 6.58 \\
\hline $\begin{array}{l}\text { Fixed term } \\
\text { written) }\end{array}$ & -0.104 & 0.009 & 0.13 & 1,024 & 8.99 \\
\hline Verbal agreement & -0.346 & 0.249 & 0.92 & 8,316 & 73.01 \\
\hline No contract & 2.573 & 0.907 & 12.75 & 2,752 & 24.16 \\
\hline Payslip & -0.619 & 0.907 & 3.02 & 8,639 & 75.84 \\
\hline Possess a payslip & & & $\mathbf{1 5 . 3 6}$ & & \\
\hline No payslip & 2.653 & 0.881 & 12.60 & 2,548 & 22.37 \\
\hline Social security & -0.584 & 0.881 & 2.76 & 8,843 & 77.63 \\
\hline Affiliated to NSIF & & & & & \\
\hline $\begin{array}{l}\text { Not affiliated to } \\
\text { NSIF }\end{array}$ & & & & & \\
\hline
\end{tabular}

\footnotetext{
${ }^{12}$ Note that the adjusted inertia approach, proposed by Benzecri (1979), to measure the quantity of information brought by an axis can only be used for an axis, $\alpha$, with principal inertia (eigenvalue) $\lambda_{a} \leq 1 / K$ (Nenadic and Greenacre 2007: 7).
} 


\begin{tabular}{|c|c|c|c|c|c|}
\hline Job satisfaction & & & 7.36 & & \\
\hline $\begin{array}{l}\text { Training matches } \\
\text { job }\end{array}$ & 1.216 & 0.425 & 4.86 & 4,503 & 39.53 \\
\hline $\begin{array}{l}\text { Training does not } \\
\text { match job }\end{array}$ & -0.615 & 0.425 & 2.50 & 6,888 & 60.47 \\
\hline $\begin{array}{l}\text { Under- } \\
\text { employment }\end{array}$ & & & 1.18 & & \\
\hline $\begin{array}{l}\text { Less hours fixed } \\
\text { by employer }\end{array}$ & 1.226 & 0.012 & 0.26 & 224 & 1.97 \\
\hline Indifferent & 0.102 & 0.034 & 0.13 & 9,607 & 84.34 \\
\hline $\begin{array}{l}\text { Less hours due to } \\
\text { economic situation }\end{array}$ & -0.708 & 0.007 & 0.13 & 305 & 2.68 \\
\hline $\begin{array}{l}\text { Less hours due to } \\
\text { health problems } \\
\text { and domestic work }\end{array}$ & -0.779 & 0.044 & 0.66 & 1,255 & 11.02 \\
\hline Remuneration & & & 14.98 & & \\
\hline Fixed salary & 1.697 & 0.336 & 4.86 & 2,378 & 20.88 \\
\hline Daily/hourly pay & 3.115 & 0.406 & 6.57 & 1,080 & 9.48 \\
\hline Indifferent & -0.173 & 0.001 & 0.00 & 157 & 1.38 \\
\hline Piece rate & -0.290 & 0.008 & 0.13 & 319 & 2.80 \\
\hline $\begin{array}{l}\text { Commissions/bene } \\
\text { fits }\end{array}$ & -0.677 & 0.678 & 3.29 & 7,324 & 64.30 \\
\hline $\begin{array}{l}\text { In-kind and no } \\
\text { payment }\end{array}$ & -0.606 & 0.007 & 0.13 & 133 & 1.17 \\
\hline Labour status & & & 8.8 & & \\
\hline $\begin{array}{l}\text { Permanent } \\
\text { regular }\end{array}$ & 0.066 & 0.004 & 0.13 & 7,116 & 62.47 \\
\hline $\begin{array}{l}\text { Permanent } \\
\text { seasonal }\end{array}$ & 2.967 & 0.389 & 6.30 & 1,106 & 9.71 \\
\hline Indifferent & -0.774 & 0.155 & 1.84 & 2,318 & 20.35 \\
\hline $\begin{array}{l}\text { Temporary } \\
\text { undefined/defined }\end{array}$ & -0.212 & 0.021 & 0.53 & 851 & 7.47 \\
\hline $\begin{array}{l}\text { Housing } \\
\text { allowance }\end{array}$ & & & 14.45 & & \\
\hline $\begin{array}{l}\text { Receive housing } \\
\text { allowance }\end{array}$ & 2.834 & 0.828 & 12.22 & 2,171 & 19.06 \\
\hline $\begin{array}{l}\text { Do not Receive } \\
\text { housing allowance }\end{array}$ & -0.513 & 0.828 & 2.23 & 9,22 & 80.94 \\
\hline Paid leaves & & & 15.31 & & \\
\hline $\begin{array}{l}\text { Perceive paid } \\
\text { leaves }\end{array}$ & 2.697 & 0.891 & 12.75 & 2,469 & 21.68 \\
\hline $\begin{array}{l}\text { Do not perceive } \\
\text { paid leaves }\end{array}$ & -0.580 & 0.891 & 2.56 & 8,922 & 78.32 \\
\hline $\begin{array}{l}\text { Union } \\
\text { membership }\end{array}$ & & & 0.26 & & \\
\hline $\begin{array}{l}\text { Member of a trade } \\
\text { union/association }\end{array}$ & 0.194 & 0.019 & 0.13 & 5,351 & 46.98 \\
\hline $\begin{array}{l}\text { Not a member of a } \\
\text { trade union/ } \\
\text { association }\end{array}$ & -0.169 & 0.019 & 0.13 & 6,04 & 53.02 \\
\hline
\end{tabular}

Source: Constructed by author with help of STATA 10 using CHCS III. 
We normalise the indicator predicted from the first axis using:

$$
\widetilde{C}_{l}=\left(C_{i}-r \min (C)\right) /(r \max (C)-r \min (C))^{13}
$$

The normalised indicator $\widetilde{C}_{l}$ classifies workers in terms of increasing employment decency, with values ranging from 0 to 1 .

\section{Appendix 2. Reduced form Estimates of Employment Decency and Income Production Function}

Employment decency intensity: ranges from 0 to 1 for household heads actively employed in the private sector and having a decent job is not a fruit of a random process, implying the problem of potential endogeneity. Again, there can be a non-linear interaction between this endogenous regressor and unobserved variables, implying the problem of heterogeneity bias. This way, standard OLS regression stands to be limited.

Results in Table A4 cleanse the structural equation estimates of potential endogeneity and unobserved heterogeneity biases. Thus, in Table A4, additional regressors arise: the residual of employment decency is generated from the reduce form equation (Table A3b) and included as additional regressor to check for potential endogeneity and the interaction term (interaction of employment decency and its residual) is also generated and included in the structural equation to account for unobserved heterogeneity.

Table A3a: Density of Institutions per Region

\begin{tabular}{|c|c|c|c|c|c|c|c|c|c|}
\hline Adamawa & Centre & East & $\begin{array}{c}\text { Far } \\
\text { North }\end{array}$ & Littoral & North & $\begin{array}{c}\text { North } \\
\text { West }\end{array}$ & West & South & $\begin{array}{c}\text { South } \\
\text { West }\end{array}$ \\
\hline 17 & 51 & 23 & 43 & 30 & 17 & 33 & 36 & 26 & 29 \\
\hline
\end{tabular}

Source: The density of regional institutions is extracted from the Presidential Decree $N^{\circ} 2008 / 376$ of November 2008 based on Administrative Organisation in Cameroon.

\section{Excluded Variables versus Employment Decency}

Table A3b submits the reduced-form estimates of the endogenous variable, employment decency. The density of institutions per region (measured by the number of subdivisions per region, Table A3a) and attachment to traditional believes measured as cluster level mean, are used as instruments to settle the endogeneity of employment decency.

In almost every country today, governments have an unquestionable responsibility in ensuring decent working conditions among individuals. Vulnerability is related to the risks, shocks, and stresses to which a household head is subjected and the state of being defenceless or the lack of means to cope with these risks, shocks, stresses, or demands (Pagés 2003: 9). The sources of these risks, among other things, may include institutions governing resource access and contract enforcement, working conditions, together with labour and commodity

\footnotetext{
${ }^{13}$ Note that $r \max$ and $r \min$ simply mean absolute maximum and minimum respectively.
} 
markets as a whole. We argue that the regional spread of administrative institutions and institutional change may help household heads in their efforts to attain decent employment status. Almost every household in Cameroon would be capable of developing better working conditions if the regional institutions implement policies and programmes related to contract enforcement, minimum wages, social security and other decent work facets.

Table A3b: Reduced-form Estimates of Employment Decency

\begin{tabular}{|l|c|c|c|c|}
\hline Employment decency index & Coef. & Std. Err. & $\mathrm{t}$ & $\mathrm{P}>\mathrm{t}$ \\
\hline Density of institutions (per region) & 2.950529 & 0.467525 & 6.31 & 0.000 \\
\hline Attachment to traditional beliefs (cluster level) & -13.4048 & 1.808478 & -7.41 & 0.000 \\
\hline Labour experience & 0.197382 & 0.04417 & 4.47 & 0.000 \\
\hline Labour experience squared & -0.00253 & 0.00058 & -4.36 & 0.000 \\
\hline Years of education & 0.873387 & 0.039978 & 21.85 & 0.000 \\
\hline Seniority in the enterprise & 5.036394 & 0.55433 & 9.09 & 0.000 \\
\hline Access to microcredit (cluster level) & 0.106367 & 1.606801 & 0.07 & 0.947 \\
\hline Number of younger children (cluster level) & -0.27893 & 0.114236 & -2.44 & 0.015 \\
\hline Number of married household heads (cluster level) & -2.92702 & 0.810263 & -3.61 & 0.000 \\
\hline Gender of household head (male =1) & 2.948296 & 0.378777 & 7.78 & 0.000 \\
\hline Location of household head (urban $=1)$ & 6.094944 & 0.350972 & 17.37 & 0.000 \\
\hline Constant & -0.48557 & 1.0395 & -0.47 & 0.640 \\
\hline Number of obs = & 9219 & & & \\
\hline F( 11, 9207) $=$ & 195.87 & & & \\
\hline Prob $>$ F = & 0.0000 & & & \\
\hline Adj R-squared = & 0.1887 & & & \\
\hline
\end{tabular}

The government and her regional institutions have, as duty, to encourage a general attitude in the population about the quality of work and favourable working conditions. The formal institutions, found in each sub-division, range from civil and municipal administrations, law and order, to ministerial delegations. Each sub-division in Cameroon is generally endowed with these institutions; the more there are sub-divisions in a region, the higher the institutional coverage in this region. Thus, we consider the number of sub-divisions in a region to capture its institutional coverage.

The density of institutions which represents the institutional coverage in each region is positively and significantly associated with employment decency. This implies that decision making to increase decent employment among private sector workers in Cameroon should also be seen from the angle of institutional strength in regions. Regional institutions (civil and municipal administrations, law and order, ministerial delegations, and trade unions) can play a vital role in encouraging a general attitude among private sector workers about the quality of work and favourable working conditions. This sense of judgment corroborates that which is underlined in North (1990) on the role of institutions. 
The average number of household heads who are attached to traditional believes and doctrines captured as cluster level means, is negative and significant in determining employment decency. This is indication that traditional attachment adversely affects a household head's social and economic interactions, limiting the individual's ability to deal with household and economic shocks like unemployment, birth and illness; exposing the latter to greater chances of accepting a vulnerable job in order to cope with these shocks.

Table A4: Income Production Function - Dependent Variable is log of Household Per Capita Monthly Income

\begin{tabular}{|l|c|c|c|c|}
\hline log of Household Per Capita Monthly Income & Coef. & Std. Err. & $\mathrm{t}$ & $\mathrm{P}>\mathrm{t}$ \\
\hline Employment decency index & 778.0058 & 140.0138 & 5.56 & 0.000 \\
\hline Labour experience & 271.118 & 49.0692 & 5.53 & 0.000 \\
\hline Labour experience squared & -2.37831 & 0.698273 & -3.41 & 0.001 \\
\hline Years of education & 763.8185 & 129.0371 & 5.92 & 0.000 \\
\hline Seniority in the enterprise & 9105.985 & 965.3059 & 9.43 & 0.000 \\
\hline Access to microcredit (cluster level) & 7061.49 & 2028.041 & 3.48 & 0.001 \\
\hline Number of younger children (cluster level) & -2460.62 & 149.986 & -16.41 & 0.000 \\
\hline Number of married household heads (cluster level) & 6929.005 & 957.5722 & 7.24 & 0.000 \\
\hline Gender of household head (male =1) & -1727.62 & 621.924 & -2.78 & 0.005 \\
\hline Location of household head (urban =1) & 7126.559 & 970.365 & 7.34 & 0.000 \\
\hline Predicted decency residual & -400.555 & 141.1234 & -2.84 & 0.005 \\
\hline Interaction of decency and its residual & -3.12306 & 0.565466 & -5.52 & 0.000 \\
\hline Number of obs = & 9219 & & & \\
\hline F( 12, 9207) = & 1440.85 & & & \\
\hline Prob > F $=$ & 0.0000 & & & \\
\hline Adj R-squared = & 0.6521 & & & \\
\hline Source: Conpun & & & \\
\hline
\end{tabular}

Source: Computed by author using ECAM III. 
